\title{
Organization Citizenship and Employee Withdrawal Behavior in the Workplace
}

\author{
Dr. J. R. Smith, (Corresponding Author) \\ Jackson State University, Department of Management and Marketing \\ P. O. Box 18230, Jackson, MS 39217-0730 USA \\ Email: jrsmith@jsums.edu
}

Dr. Lisa A. Micich

Alcorn State University, School of Business

Lorman, MS USA

Dr. Douglas L. McWilliams

Jackson State University, Department of Management and Marketing

P. O. Box 18230, Jackson, MS 39217-0730 USA601-979-2978

Email: douglas.1.mcwilliams@jsums.edu

Received: July 28, 2016 Accepted: August 17, 2016 Published: August 19, 2016

doi:10.5296/ijhrs.v6i3.9916 URL: http://dx.doi.org/10.5296/ijhrs.v6i3.9916

\begin{abstract}
The purpose of this research was to investigate the effect of organizational citizenship behaviors (altruism, courtesy, sportsmanship, generalized compliance and civic virtue) on employee withdrawal behaviors (turnover, absenteeism and tardiness). Most research in the OCB literature focused on the impact of organizational citizenship behaviors on turnover, with minimal attention directed toward absenteeism and tardiness, as negative employee performance behaviors. Data were obtained from employees $(\mathrm{N}=334)$ at a municipal law enforcement agency with $(\mathrm{N}=624)$ employees resulting in a $53.53 \%$ usable response rate. Data analysis indicated that job satisfaction was directly related to organizational citizenship behavior; and organizational citizenship behavior was inversely related to overall employee withdrawal behavior. Study findings did not lend support for organizational commitment being directly related to organizational citizenship behavior. The authors specified study limitations and future research opportunities.
\end{abstract}


Keywords: Organizational citizenship behavior, Organizational commitment, Job satisfaction, Tardiness, Absenteeism, Turnover intention

\section{Introduction}

Zimmerman et al. (2016) have carefully suggested that the social and psychological literature is replete with empirical studies demonstrating relationships between psychological individual differences and withdrawal behaviors (i.e., lateness, absenteeism, and turnover); however, the literature is lacking an integrative framework to guide practitioners and scholars to conceptualize how, why and under what circumstances the relationships are observed ( $\mathrm{p}$. 498). Their research thrust (among others) was directed toward providing an overarching theoretical basis for how psychological individual differences affect withdrawal behaviors. The research reported herein is an attempt to address the research voids.

Early research suggests that organizational citizenship behavior dimensions of helping behavior, sportsmanship and civic virtue had a significant effect on employee performance on sales unit effectiveness and in manufacturing quantity and product quality (Podsakoff and MacKenzie, 1994; Podsakoff, Ahearne, and MacKenzie, 1997). Studies on the consequences of organizational citizenship behavior found significant relationships between organizational citizenship behaviors and employee performance appraisals of salespersons (MacKenzie, Podsakoff \& Fetter 1991, 1993; MacKenzie, Podsakoff \& Paine 1998, 1999; Podsakoff \& MacKenzie, 1994; Piercy, Cravens, Lane, \& Vorhies, 2006; Eder \& Eisenberger, 2008).

The literature refers to withdrawal behaviors as tardiness (lateness), absenteeism and turnover (Adler, 1981; Clegg, 1983; Rosse, 1988; Blau, 1994). Prior to the $21^{\text {st }}$ century, minimal research activity had been directed toward discerning the relationship between organizational citizenship behaviors and negative employee performance such as employee withdrawal behaviors and recently employee counterproductive behaviors (e.g. Berry, Carpenter \& Barratt, 2012; Spector, Bauer \& Fox, 2010; Fox et al., 2012; Cohen, Panter \& Turan, 2013; Meier \& Spector, 2013). Subsequently, an interest in the subject area was spearheaded by researchers in the west and nonwestern countries using diverse sampling populations as a point of analysis to explore the relationships between organizational citizenship and withdrawal behaviors (e.g. police officers in Australia, Brunetto, Shacklock \& Farr-Wharton, 2012; social workers in Israeli health care system, Carmeli, 2005; manufacturing and sales organization work groups in the northeastern U.S., Eder \& Eisenberger, 2008; elementary school teachers and administrators in Ankara, Turkey, Erdemli, 2015; employees in a financial institution in Haifa, Israel, Meisler, 2013; employees in a French-listed company, Nicolas \& Nicolas, 2015; employees in a physical education organization in Ardabil, Iran, Noroozil \& Masumabad, 2015; alumni of a business school in Fance, Paille \& Grima, 2011; employees in the tourism and hospital industry in London, England, Regts \& Molleman, 2012; employees in a vocational training organization in Ardabil, Iran, Sehbaradar \& Hasanzadeh, 2013; high school teachers in Israel, Shapira-Lishchinsky, 2012; male and female nurses employed in a hospital in northern Israel, Shapira-Lishchinsky \& Even-Zohar, 2011; 
employees from a variety of organizations in Netanya, Israel, Sharoni, et al. (2012); teachers in a middle Tennessee school district, Shockley, 2012).

Fox, Spector, Goh, Bruursema \& Kessler (2012) succinctly indicated that studies have shown a strong negative correlation between counterproductive work behavior (CWB) and organizational citizenship behavior (OCB), and opposite correlations with hypothesized antecedents (Spector \& Fox 2010a and 2010b). Cohen, Panter \& Turan's (2013) sampling of employees working in diverse industries at several levels in the organizations, findings indicated that employees low in guilt proneness engaged in counterproductive work behaviors to a greater degree than employees high in guilt proneness as predicted by gender, age, intention to turnover, interpersonal conflict at work and negative affect at work. The authors cautioned that it would be wise for employees to take into consideration guilt proneness of applicants at the initial stage of the hiring process.

Studies on the consequences of employee withdrawal behaviors have examined the negative financial impact that these behaviors have on organizational effectiveness and efficiency. Cascio (1991) and Koslowsky (2000) suggested that these costs included lost productivity, administrative costs and negative effects on coworkers. Hackett (1989, p. 235) indicated that employee absenteeism is a costly personnel problem and the estimated aggregate loss in wages and salaries to U.S. American workers was as high as \$26 billion a year (Steers \& Rhodes, 1978).

Organizational productivity or efficiency may be negatively impacted by tardiness (Blau 1994; Steers \& Rhodes, 1978) and absenteeism (Martocchio, 1992; Steers \& Rhodes, 1978). A decrease in the morale and/or work motivation of the colleagues of tardy or absent employees has also been indicated (Jamal, 1984). While any absence can be assumed to incur costs such as loss of production, there are implicit and accepted costs incurred by the organization. Such costs include temporary labor and provisions for personal leave. The aforementioned costs comprise an integral aspect of the employment contract. Turnover also has inherent costs associated with the investment made in the departing employee as well as the recruitment, selection, and training costs in hiring a new employee (Cascio, 1991; Mobley, 1982).

Research indicates that organizational citizenship behavior is significantly negatively related to turnover (Chen et al., 1998; MacKenzie, Podsakoff, \& Ahearne, 1998; Viswesvaran, 2002; Regts \& Molleman, 2012). These studies utilized actual voluntary turnover to measure turnover. The studies examined only the turnover dimension of employee withdrawal behavior. Dominguez, Marcelino, Cardona \& Fernandez (2014) conducted a comprehensive multicultural literature review of workers employed in different companies in different countries over a five year period (2009-2013) to determine causal factors as to why they leave their jobs. Analysis of results identified 89 different variables that influenced employees to leave their jobs in the organization (e.g. negative organization behaviors such as job dissatisfaction, job burnout, task withdrawals, tardiness, absentees, tardiness). 
Employee withdrawal behavior was characterized in this study as in-role behavior. Allen (1983) posits that absenteeism is one element in the measures of on-the-job performance. However, as the commonly accepted definition of in-role behavior (Katz, 1964; Katz \& Kahn, 1966; Konovsky \& Pugh, 1994; MacKenzie, Podsakoff, \& Ahearne, 1998; Organ, 1988; Podsakoff, MacKenzie, Paine, \& Bachrach, 2000; Williams \& Anderson, 1991) is that behavior which is specified in the job description, rules and regulations, or policies and procedures.

Conceptually, in-role behaviors can be viewed as a continuum of positive performance to negative performance. Chen et al. (1998) suggested that additional empirical research on the relationship between organizational citizenship behavior and turnover is necessary. This position found support from Podsakoff et al. (2000). In their extensive critical review of the theoretical and empirical literature on organizational citizenship behaviors, Podsakoff et al. (2000) suggested that empirical research investigations are warranted addressing the relationship between organizational citizenship behaviors and other forms of withdrawal behavior, like employee absenteeism, tardiness (lateness) (p. 553)

Management is increasingly interested in perpetuating positive in-role employee productivity and developing incentive programs to minimize inefficient employee performance while fostering continuous employee satisfaction and extra-role productivity in the workplace.

The present study is an effort to investigate the effects of employee organizational commitment and job satisfaction on organization citizenship behaviors and their impact on an organization's employee withdrawal behaviors (turnover, absenteeism, and tardiness [lateness]).

\section{Theoretical Foundation and Hypothesized Theoretical Model}

The social exchange theoretical foundation (model) proposes that organizational citizenship behavior is built on reciprocity between an individual and his or her supervisor, coworkers, or the organization. The amount of reciprocity is a reflection of the employee's perception of his/her ratio of inputs to outcomes, that is, perceived equity. Inputs are the variables the employee brings to the job such as education, experience or effort. Outcomes are what is received from the organization and can take various forms such as recognition from a supervisor, assistance with work from a coworker, or a desired benefit from the organization. An employee who determines that his or her outputs exceed inputs may increase the amount of organizational citizenship behaviors in which he or she engages. This assumes not only an increase in positive extra-role behaviors, but also a decrease in negative in-role behaviors such as withdrawal behaviors.

The organizational citizenship behavior and employee withdrawal behavior literature provides theoretical and empirical support for job satisfaction and organizational commitment as antecedents of organizational citizenship behavior and employee withdrawal behavior (Bateman \& Organ, 1983; Blau, 1994; Hackett, 1989; Hanisch \& Hulin, 1990; Koslowsky et al., 1997; Organ \& Konovsky, 1989; Organ \& Lingl, 1995; Riketta \& Landerer, 2002; Schappe, 1998; Wagner \& Rush, 2000; Williams \& Anderson, 1991). The relationships 
between job satisfaction and organizational citizenship behavior as well as between organizational commitment and organizational citizenship behavior were positive. The opposite was found for the relationships between job satisfaction and employee withdrawal behavior as well as between organizational commitment and employee withdrawal behavior, both of which were found to be negative. The significant effects of job satisfaction and organizational commitment on either organizational citizenship behavior or employee withdrawal behavior may be spurious since the two constructs were not included in a study at the same time. It was predicted that job satisfaction and organizational commitment were directly related to organizational citizenship behavior.

The hypothesized theoretical model (e.g. Figure 1) predicts that organizational citizenship behavior has direct effects on employee withdrawal behavior. Further, it predicts that the relationship will be a negative linear one. The model also predicts that job satisfaction and organizational commitment will have positive linear relationships with organizational citizenship behavior and that organizational citizenship behavior will mediate the relationships between job satisfaction and organizational commitment on employee withdrawal behaviors.

The hypothesized theoretical model presents the research variables job satisfaction, organizational commitment, organizational citizenship behavior and employee withdrawal behavior. The model also indicates the direction of the relationships between the constructs with "+" indicating a positive relationship and "-"indicating an inverse relationship. The model reflects the multiple relationships investigated in this study. Organizational citizenship behavior was proposed to be a consequence of both job satisfaction and organizational commitment and an antecedent to withdrawal behavior. The following hypotheses were formulated:

Hypothesis 1: Job satisfaction is directly related to organizational citizenship behavior.

Hypothesis 2: Organizational commitment is directly related to organizational citizenship behavior.

Data collection utilized three (3) instruments including the Job Satisfaction Scale, the Organizational Commitment Scale, and the Organizational Citizenship Behavior Scale. Employees completed self-reported measures of job satisfaction and organizational commitment. The supervisor completed the measure of organizational citizenship behavior on each of his or her subordinates. The proposed direct relationships between job satisfaction and organizational citizenship behavior and between organizational commitment and organizational citizenship behavior were tested using structural equation model analysis. The results of the analyses indicated the strength, direction, and significance of the relationships.

Hypothesis 3: Organizational citizenship behavior is inversely related to overall employee withdrawal behavior. 


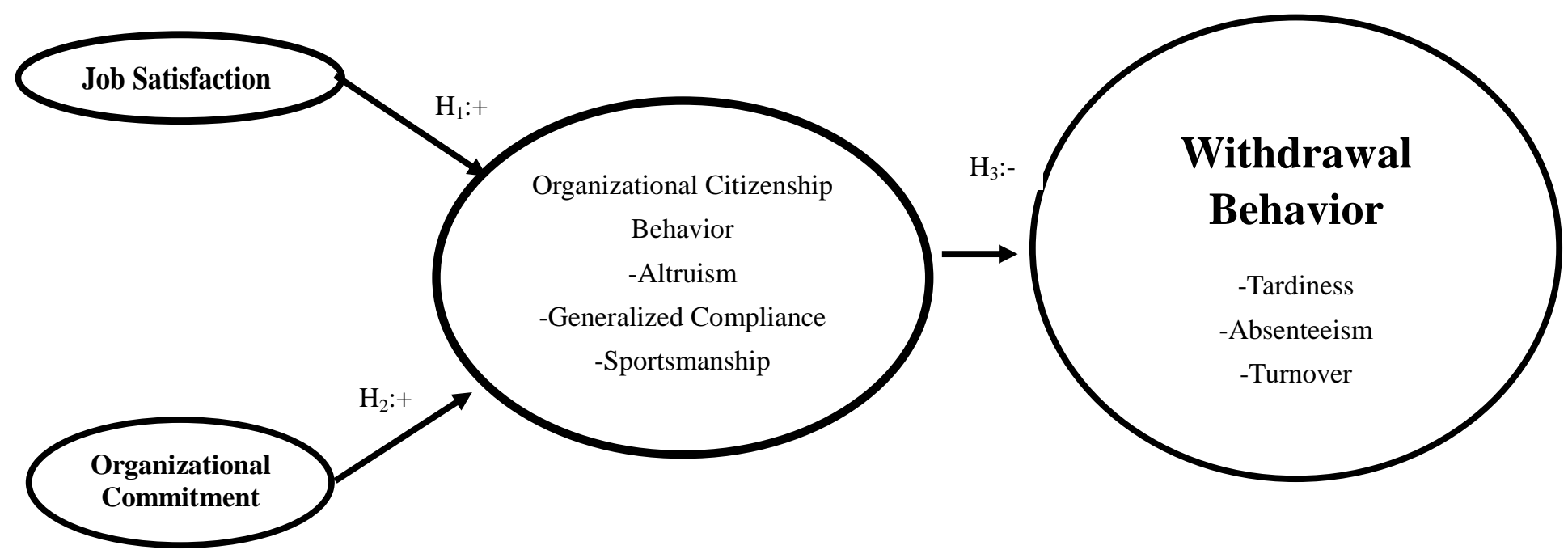

Hypothesized model arrows represents hypothesized paths

$\mathrm{H}=$ Hypothesis

$+=$ positive relationship

- $\quad=$ inverse relationship

Data were collected using two instruments, the Organizational Citizenship Behavior Scale and the Turnover Intention Scale, as well as actual tardiness and absenteeism to determine this relationship. Supervisors completed the measure of organizational citizenship behavior on the employees they supervised, and the employee completed a self-reported measure of his or her turnover intentions. Actual withdrawal behavior was captured from organizational attendance records. Analysis of the structural model was used to test the proposed direct relationship between organizational citizenship behavior and employee withdrawal behavior. The analyses outcomes indicated the strength, direction, and significance of the relationship.

\section{Method}

\subsection{Sample and Procedure}

A cross-sectional research design was used to collect data for the study from one organization at one point in time. The participating organization was a municipal law enforcement agency. This data collection site was selected after the head of this agency expressed an interest in the results of the study and, thus, consented to participation by the employees of the organization. Meetings were scheduled with each department at which time employees were provided with a description of the research study and were told that participation was 
voluntary. Employees wishing to participate were provided with the study instruments and were allowed to complete them on company time. The employees returned the instruments directly to the author. The participants were assured that their responses were for research purposes and that employee confidentiality would be maintained. The agency had 624 employees of which 53 were unable to participate in the study due to scheduling constraints. Of the remaining 571 employees, 422 participated in the study representing a $73.91 \%$ response rate. A total of 88 employees' data were rejected due to missing items, leaving 334 $(53.53 \%)$ usable responses for analyses.

Structural equation modeling was utilized to analyze the relationships between job satisfaction, organizational commitment, organizational citizenship behavior, and employee withdrawal behaviors. This study utilizes a combination of survey data and archival data to collect information on individual behaviors. Primary (survey) data was obtained from two sources - supervisors (other report) and subordinates (self-report), while secondary (archival) data were obtained from company records.

The use of multiple sources to circumvent the effects of common method variance was espoused by Podsakoff and Organ (1986). Common method variance resulting from single-source data collection has been demonstrated to bias the relationships between constructs (Avolio, Yammarino, \& Bass, 1991; Kline, Sulsky, \& Rever-Moriyama, 2000). To combat the effects of common method variance, supervisors completed an Organizational Citizenship Behavior instrument (Podsakoff et al., 1990) on each immediate subordinate (direct report) and all participating employees and supervisors were asked to complete the job satisfaction (Allen \& Meyer, 1990) and organizational commitment (Gregson, 1990) measures as well as provide demographic data. Self-report measures have been used to collect data on respondents' past behaviors and future behavior intentions as well as perceptual and affective responses (Ganster, Hennessey, \& Luthans, 1983; Podsakoff \& Organ, 1986). Thus, turnover intention (Cammann, Fichman, Jenkins, \& Klesh, 1979) was also collected from employees and supervisors.

\subsubsection{Measures}

Job satisfaction was measured using Gregson's (1990) Job Satisfaction Scale. Gregson modified the Job Descriptive Index (Smith et al., 1969) to develop a 30-item scale measuring five dimensions of job satisfaction: work, pay, promotions, supervision, and coworkers. Each dimension in the Job Satisfaction Scale was measured by six items scored using a seven-point Likert scale from one (strongly disagree) to seven (strongly agree).

Organizational Commitment. Allen and Meyer (1990) developed an organizational commitment scale measuring three components of organizational commitment - affective commitment, continuance commitment, and normative commitment. This study used the eight-item Affective Commitment Scale. The reliability for this scale (0.87) was acceptable. This affective commitment scale has been used in other studies (Blau, 1994; Moorman, Niehoff, \& Organ, 1993) and scale reliability was consistent (0.85 in the latter study). Factor analysis of the three-component organizational commitment scale resulted in a finding that affective commitment explained 58.8 percent of the variance in organizational 
commitment. This is indicative of the strength of the dimension in measuring organizational commitment.

Organization Citizenship Behavior. The Organizational Citizenship Behavior Scale developed by Podsakoff, MacKenzie, Moorman, and Fetter (1990) was used to measure organizational citizenship behavior. This instrument operationalized the components of organizational citizenship behavior - conscientiousness, sportsmanship, civic virtue, courtesy, and altruism as follows.

Conscientiousness was measured by five (5) items that include work attendance, compliance with rules and regulations, shirking work, taking extra breaks, and conscientiousness relative to coworkers. Sportsmanship was measured by five (5) items. These items include two on complaining, negativity, faultfinding, and problem exaggeration. These items were reverse scored.

Civic virtue was measured by four (4) items that include attending meetings and functions that are not required, keeping current with organizational changes, and reading organizational announcements, memoranda, etc. Courtesy was measured by five (5) items including problem prevention ( 2 items), awareness of the effects of one's own behavior on others ( 2 items), and consideration of the rights of others. Altruism was measured by five (5) items. These items all concerned helping behaviors and include helping co-workers who have been absent, who have heavy workloads, who are new, who have work related problems and general helpfulness to co-workers. The dimensions were assessed using seven-point Likert scales ranging from (1) "Strongly Disagree" to (7) "Strongly Agree."

Tardiness. This variable represents actual tardiness and was obtained from company records. Tardiness data were collected for a period two months before the administration of the surveys.

Absenteeism. Measures of absenteeism included frequency counts and duration of absence for the same two month period that tardiness was recorded. Distinctions were made between voluntary absenteeism (planned absence, e.g., personal leave) and nonvoluntary absenteeism (unplanned absence, e.g., illness, civic leave, death in the family).

Turnover Intention. Cammann et al.'s (1979) 3-item scale was used to measure turnover intention. Items used in this scale include "It is very possible I will look for a new job next year." The items were assessed using a seven-point Likert scale ranging from (1) "Strongly Disagree" to (7) "Strongly Agree." The use of turnover intention as a proxy for turnover was used in several studies (Boswell \& Olson-Buchanan, 2004; Chen et al., 1998; Hanisch \& Hulin, 1990; Masterson et al., 2000). Hanisch and Hulin (1990) suggested "behavioral intentions . . . have been found to be significantly related" to actual turnover behaviors. Using the Cammann et al. scale, Chen, Hui, and Sego (1998) reported an internal consistency coefficient $\alpha$ of 0.78 while George and Bettenhausen (1990) identified an internal consistency reliability of .87 .

Control Variables. Demographic and socioeconomic data were collected from supervisors and employees. Research has shown that some of these variables (age, gender, and 
organizational tenure) were significantly and negatively related to withdrawal behavior (Popp \& Belohlav, 1982; Hanisch \& Hulin, 1990; Tang \& Ibrahim, 1998).

\section{Analyses}

The instruments used in this research have been subjected to pilot study analyses by pioneers in the respective literature streams ( Allen \& Meyer, 1990; Cammann et al., 1979; Gregson, 1990; Podsakoff et al., 1990). In the interest of documenting that the instruments were appropriate for use in this study, a pilot study was completed. Approximately $10 \%$ of the completed instruments were randomly selected for use in the pilot study. The pilot sample was subjected to scale reliability analysis and factor analysis. Exploratory factor analyses on the four constructs, Job Satisfaction, Organizational Commitment, Organizational Citizenship Behavior, and Turnover Intentions demonstrated factorial validity. Variable reliability measures approached or exceeded Nunnally's (1978) recommended 0.70.

Exploratory factor analysis was conducted on the data to determine the underlying factor structure and to compare the internal consistency reliabilities of the instruments to that of previous studies in the literature. SPSS Version 22 was used to conduct exploratory factor analysis and to determine scale reliabilities. The respondent-item ratio was 9.96 (Job Satisfaction), 37.38 (Organizational Commitment), 99.66 (Turnover Intention) and 16.11 (Organizational Citizenship Behavior). Principle components extraction was used, extracting factors with eigen-values greater than 1.0. The exploratory factor analysis in this study used Varimax rotation and all values under 0.40 were suppressed.

We conducted the confirmatory factor analysis and structural equation modeling using Amos 5.0 (Byrne, 2001). We conducted confirmatory factor analysis to establish the discriminate validity among our study constructs. We conducted structural equation modeling to assess the hypothesized theoretical model. This analysis examined both the measurement model and the structural model inherent in SEM.

Anderson and Gerbing (1988) posit that the measurement model and the structural model should be viewed as two conceptually distinct models, the measurement and structural models were examined in two stages. The measurement model was analyzed first using confirmatory factor analysis to test the adequacy of the hypothesized factor structure. Second, the hypothesized structural relationships between exogenous and endogenous variables were tested using the structural model.

The structural model enables the researcher to test the hypothesized relationships between constructs. Specifically, the structural model tested the hypothesized relationship between job satisfaction, organizational commitment and organizational citizenship behavior. The model also tested the hypothesized relationship between organizational citizenship behavior and employee withdrawal behavior.

\section{Results}

The complete structural model is presented in Figure 2. Table 1 presents the results of the complete structural model. The table contains the hypothesized relationships, the estimate 
values (unstandardized regression weight), the standard error (S.E.), the critical ratios (C.R.), the standardized regression weights, and the significance level.

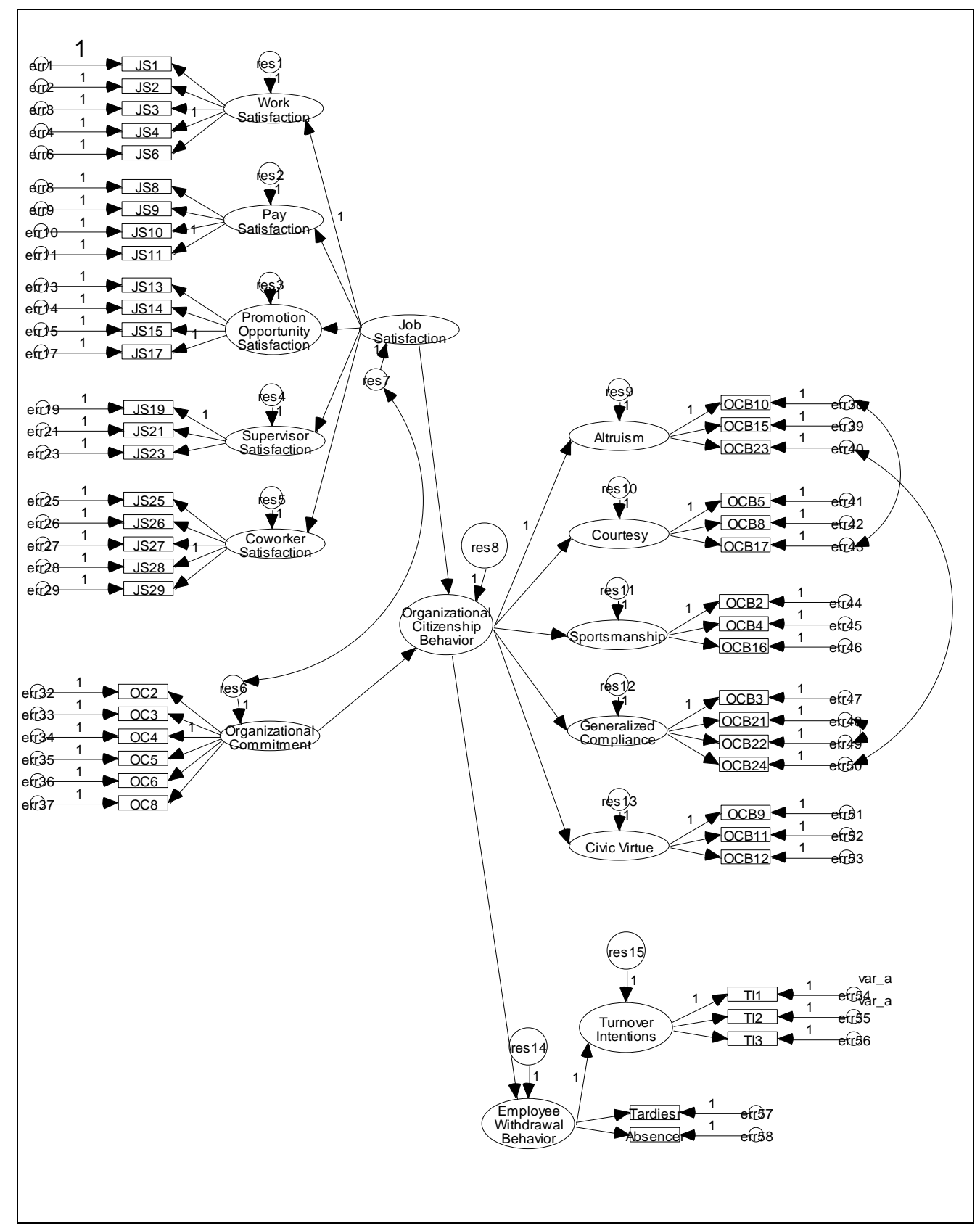

Figure 2 Complete Structural Model 
Table 1: Results of the Complete Structural Model

\begin{tabular}{|c|c|c|c|c|c|c|}
\hline $\begin{array}{l}\text { Hypothesis } \\
\text { Number }\end{array}$ & $\begin{array}{l}\text { Hypothesized } \\
\text { Relationship }\end{array}$ & Estimate & S.E. & C.R. & $\begin{array}{l}\text { Standardized } \\
\text { Regression } \\
\text { Weight }\end{array}$ & $\mathrm{P}$ \\
\hline $\mathrm{H}_{1}$ & $\mathrm{OCB} \leftarrow \mathrm{JS}$ & 1.782 & 0.785 & 2.269 & 0.535 & $\begin{array}{ll}\rho & < \\
0.05\end{array}$ \\
\hline $\mathrm{H}_{2}$ & $\mathrm{OCB} \leftarrow \mathrm{OC}$ & -0.542 & 0.284 & -1.904 & -0.351 & n.s. \\
\hline $\mathrm{H}_{3}$ & $\mathrm{EWB} \leftarrow \mathrm{OCB}$ & -0.161 & 0.068 & -2.353 & -0.379 & $\begin{array}{ll}\rho & < \\
0.05\end{array}$ \\
\hline
\end{tabular}

n.s. $=$ non-significant

Hypothesis 1 predicted that job satisfaction would have a direct relationship with organizational citizenship behavior. As indicated by the table, the hypothesized relationship between job satisfaction and organizational citizenship behavior was in the predicted direction and was significant at the $\rho<0.05$ level. Thus, Hypothesis 1 was supported.

Hypothesis 2 predicted that organizational commitment would have a direct relationship with organizational citizenship behavior. Hypothesis 2 was not supported. Contrary to hypothesized model, organizational commitment in this study was found to have an inverse relationship with organizational citizenship behavior. The relationship between organizational commitment and organizational citizenship behavior was insignificant. Williams and Anderson (1991), and Tang and Ibrahim (1998) also determined that there was no significant correlation between the two variables. MacKenzie, Podsakoff, and Ahearne (1998), Schappe (1998) and Riketta and Landerer (2002) study findings indicated that a significant relationship between organizational commitment and organizational citizenship behavior did exist. Hence, findings have been corroborative, contradictory, and inconclusive.

Finally, Hypothesis 3 predicted that organizational citizenship behavior would have an inverse relationship with employee withdrawal behavior. Hypothesis 3 was supported. The relationship between organizational citizenship behavior and employee withdrawal behavior was significant $(\rho<0.05)$ and in the hypothesized direction. This result is similar to that identified in previous studies that found a significant inverse relationship between organizational citizenship behavior and turnover (Chen et al., 1998; George \& Bettenhausen, 1990; MacKenzie, Podsakoff, \& Ahearne, 1998).

Particular interest to this study was the effect of organizational citizenship behavior on the three dimensions of employee withdrawal behavior (tardiness, absenteeism, and turnover intentions). The model was respecified to test the relationships between organizational 
citizenship behavior and tardiness, absenteeism, and turnover intentions (e.g. Table 2). The analysis indicated that the direction and significance of the relationships between job satisfaction and organizational commitment on organizational citizenship behavior remained unchanged. The results of the test of the direct effects of organizational citizenship behavior on the dimensions of employee withdrawal behavior were mixed. The relationship between organizational citizenship behavior and turnover intentions was in the predicted direction but was insignificant $(\rho>0.05)$. The relationship between organizational citizenship behavior and tardiness was in the predicted direction and was significant at the $\rho<0.001$ level. The relationship between organizational citizenship behavior and absenteeism was also in the predicted direction and was significant at the $\rho<0.01$ level.

Table 2: Results of the Re-specified Structural Model

\begin{tabular}{|l|l|l|l|l|l|}
\hline & & & & $\begin{array}{l}\text { Standardized } \\
\text { Regression } \\
\text { Weight }\end{array}$ & \\
$\begin{array}{l}\text { Hypothesized } \\
\text { Relationship }\end{array}$ & Estimate & S.E. & C.R. & P & \\
\hline OCB $\leftarrow$ JS & 1.783 & 0.786 & 2.270 & 0.536 & $\rho<.05$ \\
\hline OCB $\leftarrow$ OC & -0.541 & 0.284 & -1.904 & -0.351 & n.s. \\
\hline TI $\leftarrow$ OCB & -0.102 & 0.112 & -0.908 & -0.060 & n.s. \\
\hline Tardies $\leftarrow$ OCB & -0.209 & 0.051 & -4.093 & -0.243 & $\rho<.001$ \\
\hline Absenteeism $\leftarrow$ OCB & -0.201 & 0.064 & -3.125 & -0.187 & $\rho<.01$ \\
\hline
\end{tabular}

n.s. $=$ non-significant

\section{Discussion}

The exploratory factor and reliability analyses identified the underlying dimensions (factors) that identified the unobserved constructs. The results indicated that the constructs approached or exceeded the recommended Cronbach's alpha of 0.70 (Nunnally, 1978). Confirmatory factor analyses assessed the degree to which the expected factor structure (the model) was supported by the data. The structural model results were in the acceptable range and suggested an overall good fit of the data to the model as indicated by the model fit indices. The CMIN/DF and RMSEA results were within the range for a good fit. The CFI and TLI results approached the 0.90 benchmarks for a good fit. The GFI and AGFI results did not meet the benchmark for a good fit. Overall, there was an acceptable fit of the structural model to the data

(e.g. Table 3). The model provided support for Hypothesis 1. Hypothesis 2 was not 
supported. The major research question advanced in this study was to discern whether organizational

citizenship behaviors affect employee withdrawal behaviors. Hypothesis 3 was derived from this research question and was supported.

\subsection{Theoretical and practical implications}

The results of this research suggest employees that engage in organizational citizenship behaviors are less likely to be tardy or absent from work. Implications from the findings reported herein may be helpful to organizations implementing programs to enhance the level of organizational citizenship behavior, thus, reduce employee withdrawal behaviors that in return may lower the incidence of tardiness and absenteeism. The decrease in the level of tardiness and absenteeism may result in lowering the financial costs of withdrawal and increasing productivity.

A suggestion to enhance organizational citizenship behavior in the workplace is to put in place a test at the initial hiring process to measure prospective employee OCB. This research indicated a direct relationship exists between job satisfaction and organizational citizenship behavior. Organizations may use this information to initiate programs to enhance the level of job satisfaction among employees and minimize employee withdrawal behaviors.

Table 3: Goodness-of-Fit Model Summary for the Respecified Model

\begin{tabular}{|c|c|c|}
\hline Model & \multicolumn{2}{|c|}{ Goodness of fit if } \\
\hline CMIN/DF & 1.592 & $<2.00$ \\
\hline GFI & 0.799 & $\geq .90$ \\
\hline AGFI & 0.818 & $\geq .90$ \\
\hline CFI & 0.888 & $\geq .90$ \\
\hline TLI & 0.882 & $\geq .90$ \\
\hline RMSEA & 0.045 & $<.05$ \\
\hline
\end{tabular}

\section{Limitations and future research}

One limitation of this study was the use of a single organization for data analyses.

Limitation of study findings must be cautiously generalized. The research sample was a quasi-military organization which was quite distinct from previous studies which used samples comprised of salespersons and manufacturing employees in studying the relationship 
between organizational citizenship behavior and employee withdrawal behavior. A second limitation was the use of self-reported measures. Although mixed sources were used to mitigate the effects of sample source bias, the data for three of the variables (job satisfaction, organizational commitment, and turnover intention) were obtained through self-reports. Hence, the relationships between job satisfaction and turnover intention and between organizational commitment and turnover intention may have been overly stated. Third, the cross-sectional nature of the study limits conclusions about generalizability as well as conclusions about causality regardless of the goodness of fit results. A final limitation of the study is the restriction of withdrawal to behavioral responses. The study does not include psychological withdrawal responses such as making excuses to avoid work or drinking before going to work or on the job.

A research priority on OCB and employee withdrawal behaviors should be more in depth studies conducted in the industrial and consumer product and service industries focusing on health care and pharmaceuticals, colleges and universities, and local, state and federal government entities. Also, future research should address other antecedents (e.g., fairness, leader support, task scope, transformational and transactional leadership, trust in leader, positive affect) to discern direct or indirect effects on employee withdrawal behavior.

Organizational citizenship behavior is a recognized vital aspect of organizational dynamics. Management's ability to encourage the "good soldier syndrome" and mitigate the potential withdrawal behaviors have subsequent effects on performance measures.

\section{References}

Adler, S., \& Golan, J. (1981). Lateness as a withdrawal behavior. Journal of Applied Psychology, 66: 544-554.

Allen, N. J., \& Meyer, J. P. (1990). The measurement and antecedents of affective, continuance, and normative commitment to the organization. Journal of Occupational Psychology, 63: 1-18.

Allen, S. G. (1983). How much does absenteeism cost? The Journal of Human Resources, 28 : 379-393.

Anderson, J. C., \& Gerbing, D. W. (1988). Structural equation modeling in practice: A review and recommended two-step approach. Psychological Bulletin, 103(3), 411-423.

Avolio, B. J., Yammarino, F. J., \& Bass, B. M. (1991). Identifying common methods variance with data collected from a single source: An unresolved sticky issue. Journal of Management, 17: 571-587.

Bateman, T. S., \& Organ, D. W. (1983). Job satisfaction and the good soldier: The relationship between affect and employee "citizenship." Academy of Management Journal, 26: 587-595.

Berry, Christopher M., Carpenter, Nichelle C. \& Barratt, Claire L. (2012). Do other-reports of 
counterproductive work behavior provide an incremental contribution over self-reports? A meta-analytic comparison. Journal of Applied Psychology. 97(3):613-36.

Blau, G. (1994). Developing and testing a taxonomy of lateness behavior. Journal of Applied Psychology, 79: 959-970.

Blau, P. (1994). Social Exchange. In Structural contexts of opportunities (pp. 144-172). Chicago: The University of Chicago Press.

Boswell, W. R., \& Olson-Buchanan, J. B. (2004). Experiencing mistreatment at work: The role of grievance filing, nature of mistreatment, and employee withdrawal. Academy of Management Journal, 47: 129-139.

Brunetto, Y., Teo, S. T., Shacklock , K., \& Farr-Wharton , R. (2012). Emotional intelligence, job satisfaction, well-being and engagement: explaining organisational commitment and turnover intentions in policing . Human Resource Management Journal, 22 (4): 428-441

Byrne, B. M. (2001). Structural equation modeling with AMOS: Basic concepts, applications, and programming. Mahwah, NJ: Lawrence Erlbaum Associates.

Cammann, C., Fichman, M., Jenkins, D., \& Klesh, J. (1979). The Michigan Organizational Assessment Questionnaire. Ann Arbor, MI: University of Michigan.

Carmeli, Abraham. (2005) The relationship between organizational culture and withdrawal intentions and behavior. International Journal of Manpower 26(2):177-195

Cascio, W. F. (1991). Costing human resources: The financial impact of behavior in organizations. (3rd ed.). Boston: PWS-Kent Publishing Co.

Chen, X. P., Hui, C., \& Sego, D. J. (1998). The role or organizational citizenship behavior in turnover: Conceptualization and preliminary tests of key hypotheses. Journal of Applied Psychology, 83: 922-931.

Clegg, C. W. (1983). Psychology of employee lateness, absence, and turnover: A methodological critique and an empirical study. Journal of Applied Psychology, 68: 88-101.

Cohen, Taya R., Panter. A. T. \& Turan, Nazli . (2013). Predicting counterproductive work behavior from guilt proneness. Journal of Business Ethics. 114(1):45-53.

Domínguez A., Luis R., Marcelino, Mariana A., Cardona M,, Diego F. \& José S. Fernández, Jose S. (2014). Why people leave their jobs? International Journal of Business and Social Research, 4(11): 71-83.

Eder, Paul, \& Eisenberger, Robert. (2008). Perceived organizational support: Reducing the negative influence of coworker withdrawal behavior. DOI: 10.1177/0149206307309259 Journal of Management 2008; 34; 55.

Erdemli, Ö. (2015). Teachers' withdrawal behaviors and their relationship with work ethic. Eurasian Journal of Educational Research, 60, 201-220 Doi: 10.14689/ejer.2015.60.12 
Fox, Suzy, Spector, Paul E., Goh, Angeline, Bruursema, Kari \& Kessler, Stacey R. (2012). The deviant citizen: Measuring potential positive relations between counterproductive work behaviour and organizational citizenship behavior. Journal of Occupational and Organizational Psychology. 85:199-220

Ganster, D. C., Hennessey, H. W., \& Luthans, F. (1983). Social desirability response effects: Three alternative models. Academy of Management Journal, 26: 321-331.

George, J. M., \& Bettenhausen, K. (1990). Understanding prosocial behavior, sales performance, and turnover: A group-level analysis in a service context. Journal of Applied Psychology, 75: 698-709.

Giedrè, Genevičiūtè- Janonienè , \& Endriulaitienè, Auksè. (2014). Employees' organizational commitment: Its negative aspects for organizations. Procedia - Social and Behavioral Sciences 140: 558 - 564 .

Gregson, T. (1990). The separate constructs of communication satisfaction and job satisfaction. Educational and Psychological Measurement, 50: 39-48.

Hackett, R. D. (1989). Work attitudes and employee absenteeism: A synthesis of the literature. Journal of Occupational Psychology, 62: 235-248.

Hanisch, K. A., \& Hulin, C. L. (1990). Job attitudes and organizational withdrawal: An examination of retirement and other voluntary withdrawal behaviors. Journal of Vocational Behavior, 37: 60-78.

Jamal, M. (1984). Job stress and job performance controversy: An empirical assessment. Organizational Behavior and Human Performance, 33: 1-21.

Katz, D. (1964). The motivational basis of organizational behavior. Behavioral Science, 9: 131-146.

Katz, D., \& Kahn, R. L. (1966). The social psychology of organizations. New York: Wiley.

Kline, T. J. B., Sulsky, L., M., \& Rever-Moriyama, S. D. (2000). Common method variance and specification errors: A practical approach to detection. The Journal of Psychology, 134: 401-421.

Konovsky, M. A., \& Pugh, S. D. (1994). Citizenship behavior and social exchange. Academy of Management Journal, 37: 656-669.

Koslowsky, M. (2000). A new perspective on employee lateness. Applied Psychology: An International Review, 49: 390-407.

Koslowsky, M., Sagie, A., Krausz, M., \& Singer, A. D. (1997). Correlates of employee lateness: Some theoretical considerations. Journal of Applied Psychology, 82: 79-88.

MacKenzie, S. B., Podsakoff, P. M., \& Ahearne, M. (1998). Some possible antecedents and consequences of in-role and extra-role salesperson performance. Journal of Marketing, 62: 87-98. 


\section{Macrothink}

International Journal of Human Resource Studies

ISSN 2162-3058

2016, Vol. 6, No. 3

MacKenzie, S. B., Podsakoff, P. M., \& Fetter, R. (1991). Organizational citizenship behavior and objective productivity as determinants of managerial evaluations of salespersons' performance. Organizational Behavior and Human Decision Processes, 50, 123-150.

MacKenzie, S. B., Podsakoff, P. M., \& Fetter, R. (1993). The impact of organizational citizenship behavior on evaluations of salesperson performance. Journal of Marketing, 57: $70+$.

MacKenzie, S. B., Podsakoff, P. M., \& Paine, J. B. (1998). Effects of organizational citizenship behaviors and productivity on evaluations of performance at different hierarchical levels in sales organizations. Journal of the Academy of Marketing Science, 27: 396-410.

MacKenzie, S. B., Podsakoff, P. M., \& Paine, J. B. (1999). Do citizenship behaviors matter more for managers than for salespeople? Journal of the Academy of Marketing Science, 27: 396-410.

Martocchio, J. J. (1992). The financial cost of absence decisions. Journal of Management, 18 : 133-152.

Masterson, S. S., Lewis, K., Goldman, B. M., \& Taylor, M. S. (2000). Integrating justice and social exchange: The differing effects of fair procedures and treatment on work relationships. Academy of Management Journal, 4: 738-748.

Meier, Lavrens, L. \& Spector, Paul E. (2013). Reciprocal effects of work stressors and counterproductive work behavior: a five-wave longitudinal study. Journal of Applied Psychology. 98(3):529-39.

Meisler, G. (2013). Empirical exploration of the relationship between emotional intelligence, perceived organizational justice and turnover intentions . Employee Relations, 35(4): 441-455.

Mobley, W. H. (1982). Employee turnover: Causes, consequences and control. Reading, MA: Addison-Wesley.

Moorman, R. H., Niehoff, B. P., \& Organ, D. W. (1993). Treating employees fairly and organizational citizenship behavior: Sorting the effects of job satisfaction, organizational commitment, and procedural justice. Employee Responsibilities and Rights Journal, 6: 209-225.

Nicolas Aubert, \& Nicolas, Hollandts, Xavier. (2015). How shared capitalism affects employee withdrawal: An econometric case study of a French-listed company. The Journal of Applied Business Research-May/June 2015 31(3): 925-938.

Noroozil, Davoud, \& Masumabad, Salehe Abdi. (2015).The role of spiritual intelligence in employees' withdrawal behaviors in physical education organization. International Journal of Organizational Leadership 4:60-71.

Nunnally, J. C. (1978). Psychometric theory (2nd ed.). New York: McGraw-Hill. 


\section{Macrothink}

International Journal of Human Resource Studies

ISSN 2162-3058

2016, Vol. 6, No. 3

Organ, D. W. (1988). Organizational citizenship behavior: The good soldier syndrome. Lexington, MA: Lexington Books.

Organ, D. W., \& Konovsky, M. (1989). Cognitive versus affective determinants of organizational citizenship behavior. Journal of Applied Psychology, 74: 157-164.

Organ, D. W., \& Lingl, A. (1995). Personality, satisfaction, and organizational citizenship behavior. The Journal of Social Psychology, 135: 339-.

Ozer, Muammer. (2011). A moderated mediation model of the relationship between organizational citizenship behaviors and job performance. Journal of Applied Psychology. 96(6): q1328-36.

Paille, Pascal \& Grima, Francois. (2011). Citizenship and withdrawal in the workplace: relationship between organizational citizenship behavior, intention to leave current job and intention to leave the organization. The Journal of Social Psychology. 151(4):478-93.

Piercy, N. F., Cravens, D. W., Lane, Nikata, \& Vorhies, D. W. (2006). Driving organizational citizenship behaviors and salesperson in-role behavior performance: The role of management control and perceived organizational support. Journal of the Academy of Marketing Science, 34: 244-262.

Podsakoff, P. M., Ahearne, M., \& MacKenzie, S. B. (1997). Organizational citizenship behavior and the quantity and quality of work group performance. Journal of Applied Psychology, 82: 262-270.

Podsakoff, P. M., \& MacKenzie, S. B. (1994). Organizational citizenship behaviors and sales unit effectiveness. Journal of Marketing Research, 31: 351-363.

Podsakoff, P. M., MacKenzie, S. B., Moorman, R. H., \& Fetter, R. (1990). Transformational leader behaviors and their effects on followers' trust in leader, satisfaction, and organizational citizenship behaviors. Leadership Quarterly, 1: 107-142.

Podsakoff, P. M., MacKenzie, S. B., Paine, J. B., \& Bachrach, D. G. (2000). Organizational citizenship behaviors: A critical review of the theoretical and empirical literature and suggestions for future research. Journal of Management, 26: 513-563.

Podsakoff, P. M., \& Organ, D. W. (1986). Self-reports in organizational research: Problems and prospects. Journal of Management, 12: 531-544.

Popp, P. O., \& Belohlav, J. A. (1982). Absenteeism in a low status work environment. Academy of Management Journal, 25: 677-683.

Ratnasingam, P. (2012). Do employees mirror their supervisors' work withdrawal behaviors? Examining the supervisor-to-subordinate work withdrawal contagion phenomenon (Doctoral dissertation).University of Houston. Available from ProQuest Dissertations and Theses database. (UMI No. 3536538). 
Regts, G., \& Molleman, E. (2012). To leave or not to leave: When receiving interpersonal citizenship behavior influences an employee's turnover intention. Human Relations The Tavistock Institute, 66(193): 192-218.

Richards, David A. \& Aaron C. H. (2011). Attachment at (not to) work: applying attachment theory to explain individual behavior in organizations. Journal of Applied Psychology. 96(1):169-82.

Riketta, M., \& Landerer, A. (2002). Organizational commitment, accountability, and work behavior: A correlational study. Social Behavior and Personality, 30: 653-660.

Rosse, J. G. (1988). Relations among lateness, absence, and turnover: Is there a progression of withdrawal? Human Relations, 41: 517-531.

Schappe, S. P. (1998). The influence of job satisfaction, organizational commitment, and fairness perceptions on organizational citizenship behavior. Journal of Psychology, 132: 277-290.

Schnake, M. (1991). Organizational citizenship: A review, proposed model, and research agenda. Human Relations, 44: 735-759.

Sehbaradar, S., Ebrahimpour, H., \& Hasanzadeh, M. (2013). Investigating the relationship between organizational justice and withdrawal behaviour among the employees of Ardabil technical \& vocational training organization. International Journal of Management and Social Sciences Research (IJMSSR), 2 (3):93-99.

Shapira-Lishchinsky, Orly (2012). Teachers' withdrawal behaviors: integrating theory and findings, Journal of Educational Administration, 50(3): 307 - 326.

Shapira-Lishchinsky, Orly \& Even-Zohar, Shmuel. (2011). Withdrawal behaviors syndrome: An ethical perspective. Journal of Business Ethics, 103: 429-451.

Sharoni , G., Tziner , A., Fein , E. C., Shultz , T., Shaul, K., \& Zilberman , L. (2012). Organizational citizenship behavior and turnover intentions: Do organizational culture and justice moderate their relationship? Journal of Applied Social Psychology, 42 (S1): E267-E294.

Shockley, K. (2012). Factors influencing teacher absenteeism in a Middle Tennessee school system. (Doctoral dissertation).Tennessee State University. Paper AAI3552863.

Smith, P. C., Kendall, L. M., \& Hulin, C. L. (1969). The measurement of satisfaction in work and retirement. Chicago, IL: Rand McNally.

Spector, Paul E., Bauer, Jeremy A. \& Fox, Suzy. (2010). Measurement artifacts in the assessment of counterproductive work behavior and organizational citizenship behavior: Do we know what we think we know? Journal of Applied Psychology, 95(4):781-790.

Spector, Paul E., \& Fox, Suzy. (2010a). Counterproductive work behavior and organizational citizenship behavior: Are they opposite forms of active behavior? Applied psychology: An international review, 59: 21-39. 


\section{Macrothink}

International Journal of Human Resource Studies

ISSN 2162-3058 2016, Vol. 6, No. 3

Spector, P. E., \& Fox, S. (2010b). Theorizing about the deviant citizen: An attributional explanation of the interplay of organizational citizenship and counterproductive work behavior. Human Resource Management Review, 20: 132-143.

Steers, R. M., \& Rhodes, S. R. (1978). Major influences on employee attendance: A process model. Journal of Applied Psychology, 63: 391-407.

Tang, T. L. P., \& Ibrahim, A. H. S. (1998). Antecedents of organizational citizenship behavior revisited: Public personnel in the United States and in the Middle East. Public Personnel Management, 27: 529-550.

Viswesvaran, C. (2002). Absenteeism and measures of job performance: a meta-analysis. International Journal of Selection and Assessment, 10: 12-17.

Wagner, S. L., \& Rush, M. C. (2000). Altruistic organizational citizenship behavior: Context, disposition, and age. The Journal of Social Psychology, 140: 379-391.

Williams, L. J., \& Anderson, S. E. (1991). Job satisfaction and organizational commitment as predictors of organizational citizenship and in-role behaviors. Journal of Management, 17: 601-617.

Zimmerman, Ryan D.; Swider, Brian W.; Woo, Sang Eun; \& Allen, David G. (2016).Who withdraws? Psychological individual differences and employee withdrawal behaviors. Journal of Applied Psychology Apr 2016, 101(4): 498-519.

\section{Copyright Disclaimer}

Copyright for this article is retained by the author(s), with first publication rights granted to the journal.

This is an open-access article distributed under the terms and conditions of the Creative Commons Attribution license (http://creativecommons.org/licenses/by/3.0/). 